\title{
Foundational text gets a second edition
}

\author{
Robert I. Colautti' \\ I Biology Department, Queen's University, 116 Barrie St., Kingston, ON, K7L 3N6 Canada \\ Corresponding author: Robert Colautti (robert.colautti@queensu.ca)
}

Academic editor: Ingolf Kühn | Received 12 November 2021 | Accepted 13 December 2021 | Published 6 January 2022

Citation: Colautti RI (2022) Foundational text gets a second edition. NeoBiota 71: 49-50. https://doi.org/10.3897/ neobiota.71.77920

Invasion biology, as a discipline, has grown along a trajectory that is commonly observed in biological invasions themselves - an early establishment initiates a lag phase followed much later by exponential growth. As measured by the number of peer-reviewed journal articles, the log-phase of invasion biology begins around 1990 but the lag phase stretches back centuries to observations by Charles Darwin and Alexander von Humbolt (Chew 2011). Along this trajectory there is likely no single contribution that has been more influential to the modern field of invasion biology than Charles Elton's book "The Ecology of Invasions by Animals and Plants" (Elton 1958).

Reprinted in 2000 with a foreword by Daniel Simberloff (Elton 2000), I remember reading The Ecology of Invasions and how much it impacted my early studies as an undergraduate research assistant. More recently, the edited volume "Fifty Years of Invasion Ecology: The Legacy of Charles Elton" (Richardson 2008) updated the stateof-the art in invasion biology, with contributions from leading researchers in invasion biology and related fields.

As a key figure in the much broader fields of animal ecology and conservation biology, it perhaps isn't surprising that many influential ideas in invasion biology were introduced by Elton in 1958 and remain highly relevant to the field today. Despite its status as a foundational scientific text, The Ecology of Invasions reads less like a textbook and more like a David Attenborough narrative on the natural history of invasions. Peppered with fascinating observations of the natural world that demonstrate foundational concepts, the original text remains a 'must read' for students and trainees.

Given its prominence to the field and my personal experience, I was keen to receive a copy of the 2020 "Second Edition" of The Ecology of Invasions. In contrast to the

Copyright Robert I. Colautti. This is an open access article distributed under the terms of the Creative Commons Attribution License (CC BY 4.0), which permits unrestricted use, distribution, and reproduction in any medium, provided the original author and source are credited. 
reprint (Elton 2000) and the edited volume (Richardson 2008), the Second Edition includes the nine original chapters and Preface to which have been added New Introduction and Conclusion chapters, along with nine new Foreword chapters. Written by Anthony Ricciardi and Daniel Simberloff, the new content draw from Elton's extensive notes while updating the last sixty years of peer-reviewed research in invasion biology.

For students and trainees, the new chapters provide important context and useful updates from modern studies and observations. As a more seasoned reader with almost two decades of research in biological invasions, I enjoyed learning more about the historical context and insights into the cognition of an influential scientist gleaned from a thorough investigation of Elton's notes and marginalia.

If I have a criticism to share it is not with the book itself so much as with our collective tendency to elevate and idolize our scientific pioneers - the giants on whose shoulders we stand. While it is fair to marvel at Elton's prescient contributions to conservation biology, ecology and animal behavior it is perhaps worth recognizing the role that status and privilege play in determining who has opportunities to make such contributions. As ecologists and conservation biologists we should teach students about the history of ideas. As researchers who understand the value of diversity, perhaps we should increase efforts to reverse historical trends of under-representation. Just as stale scientific observations are updated with modern data by Ricciardi and Simberloff, maybe we should equally update pictures of men in suits, both figurative and literal, with contributions from modern researchers and practitioners who represent the diversity of ideas that define modern science.

Of course, it is unfair to place the blame on the authors of this book, which remains perhaps the best introduction to the field of biological invasions. With Charles Elton's death in 1991, this important contribution by Ricciardi and Simberloff is likely as close as we can get to a second edition of the most influential book in the field of invasion biology.

\section{References}

Chew MK (2011) Invasion biology: historical precedents In: Simberloff D, Rejmánek M (Eds) Encyclopedia of Biological Invasions. University of California Press (Los Angeles): 369374. [ISBN: 9780520264212] https://doi.org/10.1525/9780520948433-084

Elton CS (1958) The Ecology of Invasions by Animals and Plants. Methuen, London, 181 pp. [ISBN: 9780412114304] https://doi.org/10.1007/978-1-4899-7214-9

Elton CS (2000) The Ecology of Invasions by Animals and Plants. University of Chicago Press, Chicago, 196 pp. [ISBN: 9780226206387]

Richardson DM [Ed.] (2008) Fifty Years of Invasion Ecology: The Legacy of Charles Elton. Wiley, West Sussex, 456 pp. [ISBN:9781444335859] https://doi.org/10.1111/j.14724642.2007.00464.x 